\title{
HUBUNGAN SIKAP MASYARAKAT DENGAN KEPATUHAN PENGOBATAN MASSAL FILARIASIS DI KECAMATAN BAKTIYA ACEH UTARA
}

\author{
Yuziani $^{1}$, Mulyati Sri Rahayu ${ }^{1}$ \\ 1) Program Studi Pendidikan Dokter, Fakultas Kedokteran, Universitas Malikussaleh \\ Jl. H. Meunasah Uteunkot, Cunda, Lhokseumawe \\ Corresponding author: yuziani@unimal.ac.id
}

\begin{abstract}
Abstrak
Filariasis masih menjadi salah satu masalah kesehatan masyarakat di Kabupaten Aceh Utara dan angka kejadian tertinggi tingkat propinsi Aceh. Kecamatan Baktiya paling tinggi angka kejadian di Aceh utara. Filariasis merupakan penyakit menular menahun yang disebabkan oleh cacing filarial, yang menimbukan pembengkakan pada tangan, kaki dan genital.Salah satu strategi pemberantasan filariasis yang dilakukan dengan memutuskan mata rantai penularan dengan Pemberian Obat Masal Pencegahan (POMP) filariasis. Keberhasilan pengobatan sangat tergantung dari sikap masyarakat menyingkapi pengobatan ini. Penelitian bertujuan mengetahui hubungan sikap Masyarakat dengan kepatuhan pengobatan massal filariasis di Kecamatan Baktiya Aceh Utara. Jenis penelitian ini adalah analitik observasional dengan menggunakan pendekatan cross-sectional, sampel yang digunakan pada penelitian ini sebanyak 256 sample dan analisis data menggunkan uji Chi-Square dan Uji Kolmogorov Smirnov sebagai alternatif lain untuk pemenuhan syarat. Didapatkan hasil responden dengan rentang umur terbanyak yaitu berada pada usia 17-25 yaitu 43,4\%. Distribusi jenis kelamin responden terbanyak adalah jenis kelamin laki-laki yaitu 52,3\%. Distribusi pendidikan terakhir responden terbanyak adalah tamat SMA/MA/SMK yaitu 52,3\%. Distribusi pekerjaan responden terbanyak adalah IRT yaitu sebanyak 20,3\%. Gambaran tingkat sikap masyarakat tentang filariasis ada pada tingkatan kurang yaitu sebanyak 55,9\%, dan hanya 2,7 \% yang memiliki tingkat sikap baik tentang filariasis sedangkan kepatuhan pengobatan massal filariasis didapatkan hanya 2,7\% yang diketahui patuh dalam mengkonsumsi obat filariasis, sedangkan 97,3 \% diketahui tidak patuh. Kesimpulan bahwa tidak ada hubungan antara tingkat sikap masyarakat dengan kepatuhan pengobatan Massal Filariasis pada masyarakat di Kecamatan Baktiya, Aceh Utara Periode 2015-2018.
\end{abstract}

Kata kunci: sikap masyarakat, kepatuhan pengobatan massal, filariasis, kecamatan baktiya, aceh utara.

\section{Relationships of Community Attitudes with the Compliance of Mass Filariasis in The District of Baktiya Aceh Utara}

\begin{abstract}
Antibiotics are one of the most widely used drugs. The use of antibiotics is very widespread supported by the ease with which antibiotics are bought at pharmacies without a doctor's prescription. Antibiotics can reduce the rate of bacterial infections if used according to the right rules. The use of antibiotics without a doctor's prescription is now more widespread and has the effect of increasing the development of bacteria that are resistant to antibiotics. Knowledge of the rules of use and the mechanism of action of antibiotics is very
\end{abstract}


important to be studied by health science students, especially by medical students. This study aims to determine the knowledge of the use of antibiotics among students of the Medical Study Program FK Unimal 2019 Class. This research is a descriptive study, using a cross sectional method with a total sampling of 96 respondents who met the inclusion and exclusion criteria. The results of the study are presented as univariate descriptive analysis with tables. The results of research on the level of knowledge of students of the Medical Study Program Malikussaleh University in 2019 on the use of antibiotics, there were $87.5 \%$ who had good knowledge, $12.5 \%$ moderate knowledge and did not find students who had less knowledge.

Keywords: community attitudes, compliance with mass medicine, filariasis, baktiya district, north aceh.

\section{PENDAHULUAN}

Filariasis menyebar di seluruh wilayah indonesia, di beberapa daerah mempunyai tingkat endemisitas yang cukup tinggi, Aceh termasuk endemis filariasis. Filariasis atau kaki gajah adalah penyakit menular menahun yang disebabkan oleh parasit berupa cacing filaria, dan merupakan penyakit tropis yang terabaikan. Penyakit ini menyerang saluran dan kelenjar getah bening dan kemudian dapat merusak sistem limfe, menimbulkan pembengkakan pada tangan, kaki, glandula mammae, dan scrotum, menimbulkan cacat seumur hidup serta stigma sosial bagi penderita dan keluarganya. (1)

World Health Assembly menetapkan resolusi "Elimination of Lymphatic Filariasis as a Public Health Problem", yang kemudian pada tahun 2000 diperkuat dengan keputusan WHO dengan mendeklarasikan "The Global Goal of Lymphatic Filariasis as a Public Health Problem by the Year 2020". Indonesia sepakat untuk ikut serta dalam eliminasi filariasis global yang ditandai dengan pencanangan dimulainya eliminasi filarisis di Indonesia oleh Menteri Kesehatan pada tanggal 8 April 2002. sehingga diharapkan komitmen dari pemerintah, provinsi dan kabupaten/kota akan meningkat. (2)

Untuk mempercepat terwujudnya Indonesia bebas kaki gajah, maka dicanangkanlah Bulan Eliminasi Kaki Gajah (Belkaga) pada Bulan Oktober periode Tahun 2015-2020, program ini menerapkan diharuskannya minum obat filariasis kepada setiap penduduk kabupaten/kota endemis kaki gajah secara serentak pada bulan Oktober. Belkaga telah dilaksanakan pada tanggal 1 Oktober 2015 dan diharapkan semua kabupaten/kota endemis filariasis mulai melaksanakan POPM Filariasis paling lambat tahun 2016 sehingga pada tahun 2020 rangkaian siklus POPM selama 5 tahun diharapkan selesai dilaksanakan. (3)

Dinas Kesehatan Provinsi Aceh melalui Dinas Kesehatan kabupaten/kota juga menetapkan upaya pencegahan filariasis melalui kegiatan eliminasi kaki gajah yang akan dilaksanakan sampai dengan 2019, dengan target pada tahun 2020 Aceh akan menjadi 
daerah eliminasi Filariasis. Aceh Utara merupakan salah satu daerah endemis penyakit kaki gajah, pencanangan bulan eliminasi kaki gajah di Aceh Utara dilaksanakan sejak tahun 2015 hingga tahun 2019. (4)

Program global filariasis dari WHO yaitu memutuskan rantai penularan filariasis, mencegah serta membatasi kecacatan, satuan lokasi pelaksanaan eliminasi filariasis adalah kabupaten/kota, dan mencegah penyebaran filariasis antar kabupaten, provinsi dan negara. Strategi yang dilakukan dalam mendukung program tersebut yaitu memutuskan rantai penularan filariasis melalui pengobatan massal di daerah endemis (POPM) dan pengendalian vektor secara terpadu (5).

Tujuan Kegiatan POPM Filariasis yakni terselenggaranya kegiatan POPM Filariasis yang terencana dengan baik terhadap seluruh penduduk sasaran di daerah endemis filariasis (Kabupaten/Kota Endemis Filariasis) dengan cakupan lebih dari 85\% jumlah penduduk sasaran pengobatan dan $65 \%$ dari jumlah penduduk total, sehingga dapat menurunkan angka microfilaria rate menjadi $<1 \%$, menurunnya kepadatan rata-rata mikrofilaria dan terputusnya rantai penularan Filariasis. Adapun sasaran dari kegiatan POPM Filariasis ini dilaksanakan terhadap semua penduduk usia 2 tahun sampai dengan usia 70 tahun di seluruh wilayah Kabupaten/Kota Endemis filariasis. (1)

Ada banyak faktor berpengaruh terhadap kepatuhan pengobatan POPM filariasis. Keberhasilan pengobatan juga dipengaruhi oleh sikap masyarakat. Dimana Sikap adalah suatu bentuk evaluasi atau reaksi terhadap suatu objek, memihak atau tidak memihak yang merupakan keteraturan tertentu dalam hal perasaan, pemikiran, dan predisposisi tindakan seseorang terhadap suatu aspek di lingkungan sekitarnya (6). Oleh karena itu untuk meningkatkan keberhasilan POPM filariasis di Aceh Utara, perlu diketahui apakah ada hubungan sikap masyarakat tentang filariasis terhadap kepatuhan pengobatan massal filariasis pada masyarakat di daerah endemis filariasis pada masyarakat di Kecamatan Baktiya Aceh Utara.

\section{METODE PENELITIAN}

Penelitian ini menggunakan desain penelitian analitik observasional dengan pendekatan Cross Sectional, karena pengukuran variabel bebas sikap masyarakat dengan variabel terikat kepatuhan pengobatan massal filariasis dilakukan sekali waktu pada saat 
yang bersamaan. Penelitian dilaksanakan di Kecamatan Baktiya, Aceh Utara, yang terdiri dari 57 desa. Penelitian ini dilakukan mulai bulan Agustus 2018 hingga Februari 2019.

Semua anggota populasi yang dalam hal ini yang memenuhi kriteria inklusi dan eksklusi. Dimana kriteria Inklusi adalah pria dan wanita berusia 18-60 tahun.Pria dan wanita yang berdomisili tetap di Kecamatan Baktiya, Aceh Utara selama kurun waktu berjalanya progam pencegahan filariasis, dan bersedia menjadi subjek penelitian, sedangkan kriteria eksklusi adalah wanita yang sedang hamil dan penderita filariasis klinis kronis.

Teknik pengambilan sampel menggunakan rumus Lameshow dengan besar sampel minimal yang diteliti adalah 256 orang dari 57 desa di Kecamatan Baktiya, Aceh Utara. Sampel dipilih dengan menggunakan teknik probability sampling dengan cara stratified random sampling. Pengambilan teknik ini dilakukan karena sampel yang terdiri dari beberapa kelompok dengan jumlah yang berbeda. Jumlah masyarakat yang menjadi sampel penelitian pada setiap desa dihitung dengan menggunakan rumus proposional random sampling.

Data yang telah dikumpulkan, diolah dengan menggunakan program SPSS untuk di analisis dengan langkah editing, coding, entry, cleaning, tabulating, computing dengan melakukan analisis data univariat dan bivariat.

\section{HASIL}

\section{Hasil Penelitian dan Analisis}

A. Distribusi Responden Menurut Umur

Tabel 1 Distribusi Frekuensi Responden Menurut Umur

\begin{tabular}{cccc}
\hline & Umur & Frekuensi (n) & Persentase (\%) \\
\hline $17-25$ & & 111 & 43,3 \\
$26-35$ & 48 & 18,8 \\
$36-45$ & 58 & 22,7 \\
$46-55$ & 33 & 12,9 \\
$56-65$ & Total & 6 & 2,3 \\
\hline & 256 & 100,0 \\
\hline
\end{tabular}

(Sumber: Data Primer, 2019) 
Berdasarkan table 1 didapatkan bahwa distribusi frekuensi responden menurut umur terrbanyak pada umur 17-25 yaitu 43,4\%, dan yang terendah terdapat pada umur 56-65 yaitu $2,3 \%$.

B. Distribusi Responden Menurut Jenis Kelamin

Tabel 2 Distribusi Frekuensi Responden Menurut Jenis Kelamin

\begin{tabular}{|c|c|c|}
\hline Jenis Kelamin & Frekuensi (n) & Persentase (\%) \\
\hline Laki-laki & 134 & 52,3 \\
\hline Perempuan & 122 & 47,7 \\
\hline Total & 256 & 100,0 \\
\hline
\end{tabular}

(Sumber: Data Primer, 2019)

Berdasarkan tabel 4.2 didapatkan bahwa responden yang berjenis kelamin Lakilaki sebanyak 52,3 \% dan responden yang berjenis kelamin perempuan sebanyak 47,7 \%.

C. Distribusi Responden Menurut Pendidikan Terakhir

Tabel 3 Distribusi Frekuensi Responden Menurut Pendidikan Terakhir

\begin{tabular}{lcc}
\hline \multicolumn{1}{c}{ Pendidikan Terakhir } & Frekuensi (n) & Persentase (\%) \\
\hline Tamat SD & 32 & 12,5 \\
Tamat SMP/Mts & 48 & 18,8 \\
Tamat SMA/MA/SMK & 134 & 52,3 \\
Tamat Perguruan Tinggi & 42 & 16,4 \\
\hline \multicolumn{1}{c}{ Total } & 256 & 100,0
\end{tabular}

(Sumber: Data Primer, 2018)

Berdasarkan tabel 4.3 didapatkan bahwa distribusi frekuensi responden menurut pendidikan terakhir terbanyak adalah yang tamat SMA/MA/SMK yaitu 52,3\%, dan yang terendah adalah tamat SD yaitu $12,5 \%$. 
D. Distribusi Responden Menurut Pekerjaan

Tabel 4 Distribusi Frekuensi Responden Menurut Pekerjaan

\begin{tabular}{|c|c|c|}
\hline Pekerjaan & Frekuensi (n) & Persentase (\%) \\
\hline Buruh & 41 & 16,0 \\
\hline PNS & 29 & 11,3 \\
\hline Pegawai Swasta & 2 & 0,8 \\
\hline Wirausaha & 47 & 18,4 \\
\hline Siswa & 13 & 5,1 \\
\hline Mahasiswa & 23 & 9,0 \\
\hline IRT & 52 & 20,3 \\
\hline Tidak Bekerja & 49 & 18,4 \\
\hline Total & 256 & 100,0 \\
\hline
\end{tabular}

(Sumber: Data Primer, 2019)

Berdasarkan tabel 4.4 didapatkan distribusi frekuensi responden menurut pekerjaan terbanyak adalah IRT yaitu 20,3\%, dan yang terendah adalah pegawai swasta yaitu $0,8 \%$.

E. Distribusi Tingkat Sikap Responden

Variabel tingkat sikap didistribusikan meliputi 3 kategori, yaitu terdiri dari kurang, cukup, dan baik. Distribusi frekuensi dan persentase tingkat sikap masyarakat tentang filariasis di kecamatan Baktiya, Aceh Utara dapat dilihat pada tabel berikut.

Tabel 5 Distribusi Sikap Responden Tentang Filariasis

\begin{tabular}{|c|c|c|}
\hline Pengetahuan & Frekuensi (n) & Persentase (\%) \\
\hline Baik & 7 & 2,7 \\
\hline Cukup & 106 & 41,4 \\
\hline Kurang & 143 & 55,9 \\
\hline Total & 256 & 100,0 \\
\hline
\end{tabular}

(Sumber: Data Primer, 2019) 
Berdasarkan tabel 4.5 didapatkan responden yang mempunyai tingkat sikap baik tentang filariasis sebanyak 2,7 \%, yang mempunyai tingkat pengetahuan cukup tentang filariasis sebanyak $41,4 \%$, dan yang mempunyai tingkat pengetahuan kurang tentang filariasis sebanyak $55,9 \%$.

F. Distribusi Kepatuhan Responden

Tabel 6 Distribusi Kepatuhan Responden Pada Pengobatan Massal Filariasis

\begin{tabular}{|c|c|c|}
\hline Kepatuhan Minum Obat & Frekuensi (n) & Persentase $(\%)$ \\
\hline Tidak patuh & 249 & 97,3 \\
\hline Patuh & 7 & 2,7 \\
\hline Total & 256 & 100,0 \\
\hline
\end{tabular}

(Sumber: Data Primer, 2019)

Berdasarkan tabel 4.6 didapatkan responden yang patuh minum obat filariasis adalah hanya $2,7 \%$, dan yang tidak patuh sebanyak $97,3 \%$.

G. Hubungan tingkat sikap dengan kepatuhan pengobatan massal filariasis

Analisis bivariat digunakan untuk menjelaskan hubungan antara variabel independent dengan variabel dependent dalam penelitian ini. Variabel independent yang akan dilakukan analisis secara bivariat dalam penelitian ini adalah tingkat sikap masyarakat, sedangkan untuk variabel dependent nya adalah kepatuhan pengobatan massal filariasis. Uji statistic yang digunakan dalam analisis ini adalah crosstab dengan uji chi square dan uji Kolmogorov Smirnov. 
Tabel 7 Analisis tingkat sikap dengan kepatuhan pengobatan massal filariasis

\begin{tabular}{|c|c|c|c|c|c|c|c|}
\hline \multirow{3}{*}{ Sikap } & \multicolumn{7}{|c|}{ Kepatuhan pengobatan massal filariasis } \\
\hline & \multicolumn{2}{|c|}{ Tidak Patuh } & \multicolumn{2}{|c|}{ Patuh } & \multicolumn{2}{|c|}{ Total } & \multirow[t]{2}{*}{ P-value } \\
\hline & n & $\%$ & n & $\%$ & n & $\%$ & \\
\hline & & 28 & & 0 & 7 & 2 & \\
\hline Baik & 7 & & 0 & & & & \\
\hline Cukup & 104 & $\begin{array}{l}41, \\
8\end{array}$ & 2 & $\begin{array}{r}2 \\
8,6\end{array}$ & $\begin{array}{l}10 \\
6\end{array}$ & $\begin{array}{l}41 \\
, 4\end{array}$ & 0.995 \\
\hline Kurang & 138 & $\begin{array}{l}55 \\
4\end{array}$ & 5 & $\begin{array}{r}7 \\
1,4 \\
\end{array}$ & $\begin{array}{l}14 \\
3\end{array}$ & $\begin{array}{l}55 \\
, 9\end{array}$ & \\
\hline Total & 249 & 100 & 7 & $\begin{array}{r}1 \\
00 \\
\end{array}$ & $\begin{array}{l}25 \\
6\end{array}$ & $\begin{array}{l}10 \\
0\end{array}$ & \\
\hline
\end{tabular}

(Sumber: Data Primer, 2019)

Berdasarkan tabel 4.7 dengan menggunakan uji Chi-Square diketahui bahwa dari 143 responden $(55,9 \%)$ yang tingkat sikapnya kurang, terdapat 138 responden $(55,4 \%)$ yang kepatuhan minum obat massal filariasisnya tidak patuh, dan 5 responden $(42,9 \%)$ yang kepatuhan minum obat massal filariasisnya patuh. Hasil juga menunjukkan bahwa dari 106 responden $(41,4 \%)$ yang tingkat sikapnya cukup, terdapat 104 responden $(41,8$ \%) yang kepatuhan minum obat massal filariasisnya tidak patuh, dan 2 responden $(28,6$ \%) yang kepatuhan minum obat massal filariasisnya patuh. Sedangkan dari 7 responden $(2,7 \%)$ yang tingkat sikapnya baik, terdapat 7 responden $(2,8 \%)$ yang kepatuhan minum obat massal filariasisnya tidak patuh, dan tidak ada responden $(0,0 \%)$ yang kepatuhan minum obat massal filariasisnya patuh.

Berdasarkan uji Kolmogorov Smirnov menunjukkan bahwa pada penelitian ini Ho diterima $\mathrm{p}=0,995(>0.05)$ sehingga Ha ditolak. Hal ini menunjukkan tidak terdapat hubungan antara tingkat sikap dengan kepatuhan pengobatan massal filariasis pada masyarakat di kecamatan Baktiya Aceh Utara periode tahun 2015-2018.

\section{PEMBAHASAN}

\section{Karakteristik Responden}

Hasil dari penelitian ini menunjukkan bahwa jumlah responden penelitian dengan rentang umur terbanyak adalah berada pada usia 17-25 yaitu 43,4\%, responden pada 
rentang usia ini terdiri dari siswa, mahasiswa, dan responden yang memilih tidak melanjutkan pendidikan setelah SMA, ini menunjukkan bahwa sebagian besar penduduknya berada pada usia produktif, dan lebih sering ditemui ketika penelitian berlangsung.

Berdasarkan distribusi jenis kelamin, mayoritas responden pada penelitian ini adalah jenis kelamin laki-laki yaitu $52,3 \%$, selisih angka jenis kelamin antara laki-laki dan perempuan hanya $5 \%$, sampel terdistribusi rata berdasarkan jenis kelamin.

Hasil yang didapatkan dari distribusi pendidikan terakhir responden didapatkan bahwa jenjang pendidikan terakhir responden terbanyak adalah tamat SMA/MA/SMK adalah 52,3 \%. Hal ini menunjukkan bahwa jenjang pendidikan penduduk rata-rata sudah berada pada level menengah yang menggambarkan bahwa setiap tindakan dan perilaku penduduk tidak hanya sebatas perilaku tanpa pemikiran yang matang. Pendidikan dapat membawa wawasan atau pengetahuan seseorang. Secara umum, seseorang yang berpendidikan lebih tinggi akan mempunyai pengetahuan yang lebih luas dibandingkan dengan seseorang yang tingkat pendidikannya lebih rendah (Natoatmojo, 2003)

Sebagian besar responden dari penelitian ini adalah IRT yaitu sebanyak 20,3\% dimana saat dilakukan wawancara, yang berhasil banyak ditemui dan bersedia di wawancara adalah ibu-ibu rumah tangga, karena sebagian besar responden berada di rumah mereka saat penelitian dilakukan, berbeda dengan responden-responden lain yang bekerja.

\section{Tingkat Sikap Masyarakat Tentang Filariasis}

Hasil penelitian untuk tingkat sikap menunjukkan bahwa sebagian besar responden memiliki tingkat sikap yang kurang tentang filariasis yaitu sebanyak 55,9\%, kemudian diikuti oleh tingkat sikap yang cukup yaitu sebanyak $41,4 \%$, dan sisanya hanya $2,7 \%$ yang memiliki tingkat sikap baik tentang filariasis. Dari hasil tersebut dapat digambarkan bahwa masih sedikitnya responden yang memiliki sikap yang baik secara teori tentang filariasis dan program pengobatan pencegahan filariasis. Hasil ini sama dengan penelitian yang dilakukan oleh Suherni yang pada penelitiannya, proporsi responden dengan sikap kurang baik lebih tinggi dari responden yang berpengetahuan 
baik.(21)

Sikap merupakan faktor predisposi atau pemudah seseorang untuk melakukan perubahan perilaku. Faktor-faktor yang mempermudah atau mempredisposisi terjadinya perilaku dari sikap diharapkan dapat berpraktik baik dalam pencegahan kaki gajah.

Hasil penelitian Bahtiar. S mengemukakan bahwa kurangnya sikap masyarakat tentang filariasis adalah hal yang sangat umum dan merata di berbagai daerah dan Negara. Untuk mendapatkan partisipasi aktif dari masyarakat dalam pengobatan massal Filariasis, maka diperlukan sikap yang baik tentang Filariasis dan obat anti filariasis di masyarakat.(22).

Banyaknya responden dengan sikap kurang disebabkan karena kurangnya sosialisasi atau penyuluhan tentang filariasis yang masyarakat dapatkan dari petugas puskesmas setempat. Pada responden dengan tingkat sikap cukup tentang filariasis lebih sering terpapar dengan informasi tentang filariasis dari media elektronik dan internet.

Selain dari media elektronik, responden mendapatkan informasi tentang filariasis sebagian besar harusnya berasal dari kader dan petugas kesehatan. Kader merupakan ujung tombak dalam kelancaran kegiatan POMP, hal ini bisa dipahami karena kader berada di lapangan yang setiap saat dapat memberi motivasi sasaran untuk lebih memahami manfaat POMP sehingga responden mau datang ke pos pengobatan dan minum obat. Dukungan kader, tokoh masyarakat dan petugas kesehatan sangat dibutuhkan untuk keberhasilan eliminasi filariasis dalam hal penyebaran informasi sehingga sangat membantu perubahan sikap masyarakat, maka perlunya peningkatkan pelayanan kader dan petugas kesehatan. Sosialisasi biasanya didukung dengan adanya berbagai perkumpulan di masyarakat sehingga informasi tersampaikan dengan baik. Upaya eliminasi filariasis berbasis masyarakat menghasilkan cakupan pengobatan tinggi dipengaruhi oleh tingginya sosialisasi kepada masyarakat tentang program eliminasi filariasis. Sosialisasi dibutuhkan untuk meningkatkan pengetahuan dan sikap masyarakat tentang filariasis serta meningkatkan kesadaran untuk mencegah penyakit memalui POMP filariasis. 


\section{Kepatuhan Masyarakat Terhadap Pengobatan Massal Filariasis}

Berdasarkan hasil penelitian dari 256 responden didapatkan hanya 2,7 \% yang patuh minum obat filariasis, sedangkan sisanya yaitu 97,3\% lainnya diketahui tidak patuh dalam mengkonsumsi obat massal filariasis, Jenis kepatuhan dibagi menjadi kepatuhan penuh, dan sama sekali tidak patuh, dalam hal ini, masyarakat yang tidak patuh dan tidak mengkonsumsi obat yang diberikan termasuk dalam kategori sama sekali tidak patuh. Ketidakpatuhan pada penelitian ini dapat dilihat dari bagaimana responden menerima dan meminum obat yang telah dibagikan.

Dari hasil penelitian ini didapatkan bahwa ketidakpatuhan responden dalam mengkonsumsi obat filariasis ini dikarenakan responden tidak banyak yang memiliki pengetahuan yang baik tentang filariasis, alasan lain adalah responden takut akan efek samping yang ditimbulkan obat tersebut, dan karena responden merasa tidak sakit sehingga tidak perlu untuk mengkonsumsinya, kurangnya penyuluhan secara intensif dari dinas kesehatan terkait dan informasi tentang filariasis membuat banyak responden yang tidak menghadiri pos pembagian obat massal tersebut. Kepercayaan terhadap keberhasilan minum obat filariasis

Faktor manfaat keyakinan seseorang akan manfaat atau kemanjuran dari pengobatan akan berpegaruh terhadap kepatuhan pengobatan, dimana dri hasil wawancara yang dilakukan peneliti didapatkan bahwa masyarakat mempunyai kepercayaan bahwa tidak minum obat filariasis pun tidak beresiko pada dirinya, masyarakat juga merasa tidak perlu mengonsumsi obat jika tidak merasakan gejala, sehingga pada akhirnya menurunkan kepatuhan dalam pengobatan massal filariasis

Beberapa peneliti melaporkan adanya hubungan erat antara kepatuhan pasien berobat dengan bebrapa faktor lainnya seperti efek samping obat (Wibowo dan Soepardi 2008), penelitian tersebut sejalan dengan penelitian ini, dimana berdasarkan hasil wawancara, adanya efek samping yang ditimbulkan oleh obat pencegahan filariasis membuat responden enggan untuk meminumnya karena banyaknya aktivitas yang dilakukan sehingga akan meghambat pekerjaan responden, ini dikaitkan dengan karakteristik responden didapatkan bahwa kebanyakan responden pada penelitian ini berada pada usia produktif, mayoritas responden dengan usia produktif jika terserang penyakit akan merasa aktivitas kesehariannya terganggu. 
Hasil pengamatan peneliti juga didapatkan bahwa petugas kesehatan setempat kurang memberikan sosialisasi, petugas kesehatan seharusnya mengadakan sosialisasi kepada masyarakat untuk meningkatkan pengetahuan tentang penyakit filariasis. Sehingga masyarakat yang berpengetahuan kurang dan cukup pun tentang filariasis melaksanakan pengobatan dan menyikapi dengan benar apabila terjadi reaksi pengobatan dengan benar.

Selanjutnya petugas kesehatan juga jarang mendistribusikan obat filariasis ke rumah -rumah di desa/kelurahan, sehingga petugas tidak dapat memastikan bahwa obatobat yang diberikan dalam pencegahan massal filariasis dikonsumsi atau tidak oleh penerima obat, distribusi obat filariasis hanya pada pos pembagian obat saja, dari hasil wawancara juga didapatkan bahwa ada responden yang tidak langsung meminum obat tersebut di depan petugas.

\section{Hubungan Antara Tingkat Sikap Masyarakat Dengan Kepatuhan Pengobatan Massal Filariasis}

Berdasarkan hasil penelitian yang sudah dilakukan di kecamatan Baktiya Aceh Utara, menunjukkan bahwa tidak ada hubungan antara tingkat sikap masyarakat dengan kepatuhan pengobatan massal filariasis pada masyarakat di Kecamatan Baktiya. Hasil penelitian menunjukkan bahwa responden yang memiliki tingkat sikap yang cukup mengenai filariasis tidak membuat responden patuh terhadap pengobatan, ini dikarenakan alasan responden yang takut mengkonsumsi obat filariasis karena efek samping yang ditimbulkan, dan juga merasa tidak sakit sehingga tidak perlu meminum obat filariasis.

Hasil penelitian ini sesuai dengan penelitian Amnur,RS tentang Hubungan pengetahuan dan sikap dengan praktek minum obat dalam program(POMP) filariasis pada masyarakat Desa Sebakung Jaya RT.10 Kabupaten Penajam Paser Utara yang dilakukan pada tahun 2018 juga menunjukkan tidak ada hubungan antara sikap dengan praktek minum obat dengan nilai $p=0,277$.(23). Hasil penelitian ini juga didukung oleh penelitian Rusmanto tentang Faktor-faktor yang mempengaruhi sikap dan perilaku masyarakat terhadap kepatuhan minum obat anti filarial di RW II Kelurahan Pondok Aren, dengan nilai $\mathrm{p}=0,589$, yang menyatakan bahwa tidak ada hubungan yang 
bermakna antara sikap dengan kepatuhan minum obat filariasis dikarenakan petugas kesehatan tidak memberikan pendidikan kesehatan secara menyeluruh kepada semua kelompok umur melainkan hanya kepada ibu-ibu pengajian dan perkumpulan warga sehingga masyarakat kelompok remaja tidak mendapatkan pendidikan kesehatan dari petugas kesehatan melainkan dari sekolah atau media massa.(24).

Hasil penelitian juga dilakukan oleh Puji Astuti E et al pada tahun 2013 juga menunjukkan bahwa tingkat sikap responden tentang filaria dan pengobatannya tidak berhubungan dengan kepatuhan masyarakat dalam minum obat di Kabupaten Bandung, namun yang mempunyai pengaruh adalah praktek responden dalam pencegahan, pengendalian dan pengobatan filariasis terhadap kepatuhan minum obat di kecamatan Majalaya Kabupaten Bandung. (25)

Penelitian yang telah dilakukan menunjukkan bahwa kurangnya sikap masyarakat terhadap filariasis di Kecamatan Baktiya Aceh Utara menjadikan kecamatan tersebut menjadi wilayah dengan angka kejadian filarisis terbanyak di Aceh Utara, hasil penelitian Riskesdas 2018 menunjukkan Aceh dengan angka filariasis terbanyak ketiga setelah Maluku dan Papua pada tahun 2018, untuk hasil dari cakupan pengobatan program Pemberian Obat Massal Pencegahan (POMP) filariasis di Aceh hanya mencapai $60 \%$ dari cakupan pengobatan. Cakupan pengobatan yang rendah salah satu faktor penyebab kegagalan program eliminasi filariasis di suatu wilayah. Berbagai alasan atas rendahnya cakupan ini antara lain petugas yang tidak menyaksikan langsung masyarakat meminum obatnya, ketakutan akan efek samping obat, masyarakat merasa tidak sakit sehingga tidak harus meminum obat tersebut, dan sebagainya. Hal tersebut disebabkan karena kurangnya informasi dari petugas tentang pentingnya pengobatan massal ini sehingga tidak menjadi perhatian penting bagi masyarakat.

Pengobatan massal yang panjang dan dilakukan setiap tahun menimbulkan beberapa keluhan dan kejenuhan masyarakat yang dilibatkan, hal ini menyebabkan rendahnya cakupan pengobatan di suatu wilayah, edukasi dan kampanye secara terus menerus pada masyarakat di sekitar dapat meningkatkan kesadaran tentang pengobatan massal ini. Masyarakat yang mengetahui secara langsung dari petugas manfaat pengobatan massal akan dengan sadar dan sukarela terlibat langsung dalam program pengobatan (26). 


\section{KESIMPULAN}

1. Gambaran distribusi responden penelitian dengan rentang umur terbanyak yaitu berada pada usia 17-25 yaitu 43,4 \%. Distribusi jenis kelamin responden terbanyak adalah jenis kelamin laki-laki yaitu 52,3\%. Distribusi pendidikan terakhir responden terbanyak adalah tamat SMA/MA/SMK yaitu 52,3 \%. Distribusi pekerjaan responden terbanyak adalah IRT yaitu sebanyak 20,3\%.

2. Gambaran tingkat sikap masyarakat tentang filariasis di Kecamatan Baktiya ada pada tingkatan kurang yaitu sebanyak 55,9 \%, dan hanya 2,7 \% yang memiliki tingkat sikap baik tentang filariasis.

3. Gambaran kepatuhan pengobatan massal filariasis di Kecamatan Baktiya didapatkan hanya 2,7 \% yang diketahui patuh dalam mengkonsumsi obat filariasis, sedangkan 97,3\% diketahui tidak patuh.

4. Tidak ada hubungan antara tingkat sikap masyarakat dengan kepatuhan pengobatan Massal Filariasis pada masyarakat di Kecamatan Baktiya, Aceh Utara Periode 2015-2018.

\section{REFERENSI}

1. Kementerian Kesehatan Republik Indonesia. Peraturan Menteri Kesehatan Repubik Indonesia Nomor 94 tahun 2014, tentang Penanggulangan Filariasis. 2014; pp. 1118.

2 A. Arsunan. Epidemiologi Filariasis di Indonesia. Makassar: Masagena Press. 2016.

3 Meliyanie,G \& Andiarsa,D. Program Eliminasi Lymphatic Filariasis di Indonesia. 2017.

4 Serambinews.com. Bupati Canangkan Aceh Utara Bebas Kaki Gajah pada 2020, http://aceh.tribunnews.com/2016/10/18/bupati-canangkan-aceh-utara-bebas-kakigajah-pada-2020.

5 Yulidar. Laporan Hasil Penelitian Evaluasi Status Endemisitas Filariasis Pada Beberapa Kabupaten Di Provinsi Aceh Dengan Pemeriksaan Mikroskopis , Brugia Test dan ICT. Banda Aceh. 2016.

6 Azwar. Sikap Manusia, Teori dan Pengukurannya, ed. 2, Pusaka Pelajar, Yogyakarta. 2011.

7 Wahyono,Tri YM. (2010). Buletin Jendela Epidemiologi: Analisis Epidemiologi Deskriptif Filariasis di Indonesia. Vol 1.p.9.

8 Parasitologi Kedokteran. Parasitologi Kedokteran: Ditinjau Dari Organ Tubuh 
Yang di Serang. 1st edn. Jakarta: EGC. 2009; hal. 127-132.

9 T.Pohan.Herdiman. Ilmu Penyakit Dalam. (S. Setiati, Ed.) (2nd ed.). Jakarta Pusat: InternaPublishing. 2015.

10 Dasar Parasitologi Klinik. Dasar Parasitologi Klinik. Jakarta: Badan Penerbit FK UI. 2011; hal. 152-155.

11 Widoyono. Penyakit Tropis: Epidemiologi, Penularan, Pencegahan \& Pemberantasannya. Jakarta: Penerbit Erlangga. 2011.

12 Elytha, F. Studi Literatur: Transmission Assessment Survey Sebagai Salah Satu Langkah Penentuan Eliminasi Filariasis. Jurnal Kesehatan Masyarakat Andalas. 2014.

13 Departemen Kesehatan RI. Sistem Kesehatan Nasional. Jakarta. 2014.

14 Departemen Kesehatan RI. Situasi Filariasis di Indonesia tahun 2015. https://doi.org/ISSN .2016; 2442-7659.

15 Notoatmodjo, S. Kesehatan Masyarakat: Ilmu dan Seni, Rineka cipta, Jakarta. 2007.

16 Bart, S., Psikologi Kesehatan. Jakarta: PT Grasindo. 2004,pp. 131

17 Niven, Psikologi Kesehatan Pengantar untuk Perawat dan Profesional Kesehatan Lain. Alih Bahasa Agung Waluyo; Editor : Monica Ester. Edisi 2.Jakarta : EGC. 2002.

18 Putri, Y.R., Adriani, Kepatuhan pasien ODHA meminum obat dengan keberhasilan terapi antiretroviral (ARV). STIKes Fort De Kock, Bukittinggi. 2016

19 Dinas Kesehatan Kabupaten Aceh Utara, Data Kasus Filariasis di Kecamatan Baktiya, Aceh Utara tahun 2017.

20 Notoatmodjo, S. Metodologi Penelitian Kesehatan. Jakarta : Rineka Cipta. 2010. hal.58-59.

21 Suherni,. Faktor-faktor Yang Berhubungan dengan Perilaku Minum Obat Filariasis Pada Kegiatan Pengobatan Massal Filariasis di Kabupaten Subang Jawa Barat tahun 2007. Skripsi Progam Sarjana Kesehatan Masyarakat FKM UI Depok. 2007.

22 Bahtiar. S,. Perilaku Minum Obat Anti Filariasis Di Kelurahan Rawa Mambok. Jurnal Kesehatan Stikes Kapuas Raya Sintang.2017.

23 Amnur,RS,. Hubungan Pengetahuan dan Sikap dengan Praktek Minum Obat Dalam Program(POMP) Filariasis pada Masyarakat Desa Sebakung Jaya RT.10 Kabupaten Penajam Paser Utara. 2018.

24 Rusmanto,. Faktor-Faktor Yang Mempengaruhi Sikap dan Perilaku Masyarakat Terhadap Kepatuhan Minum Obat Anti Filaria di RW II Kelurahan Pondok Aren .. 2013.

25 Puji AE et al,. Analisis Perilaku Masyarakat Terhadap Kepatuhan Minum Obat Filariasis Di Tiga Desa Kecamatan Majalaya Kabupaten Bandung Tahun 2013.

26 Meliyanie,G \& Andiarsa,D,. Program Eliminasi Lymphatic Filariasis di Indonesia,. 2017. 